\title{
Changes in Serum Growth Hormone and Cortisol among Pregnant Women in Port Harcourt, Nigeria
}

\author{
Amadi Nnaemeka Caleb ${ }^{1}$, Chinko Bruno Chukwuemeka ${ }^{1 *}$, Green Kinikanwo Innocent ${ }^{2}$ \\ ${ }^{1}$ Department of Human Physiology, Faculty of Basic Medical Sciences, College of Health Sciences, University of Port Harcourt, Port \\ Harcourt, Nigeria \\ ${ }^{2}$ Department of Obstetrics and Gynaecology, Faculty of Clinical Sciences, College of Health Sciences, University of Port Harcourt, \\ Port Harcourt, Nigeria
}

\author{
DOI: $10.36348 / \operatorname{sijog.2022.v05i01.004~}$ \\ | Received: 11.12.2021 | Accepted: 15.01.2022 | Published: 24.01 .2022 \\ *Corresponding author: Chinko Bruno Chukwuemeka \\ Department of Human Physiology, Faculty of Basic Medical Sciences, College of Health Sciences, University of Port Harcourt, Port \\ Harcourt, Nigeria
}

\section{Abstract}

Background: Pregnancy is associated with anatomic, physiological and metabolic adaptations to accommodate the fetus and prepare the mother for delivery. These adjustments are mediated by the hormonal influences of the placenta. The study is aimed at evaluating the pattern of changes of serum growth hormone and cortisol in normal pregnancy to access the possible effect of gestational age and parity on these parameters. Methods: A cross sectional study involving a total of 300 apparently healthy females (21-50yrs) with 200 and 100 pregnant females and non-pregnant controls respectively. The age of the subjects, last menstrual period, gestational age and parity were obtained using a simple questionnaire while the weight and height were obtained following standard protocols. Blood samples were obtained from the subjects and serum growth hormone and cortisol were analyzed using standard laboratory methods. Results: Serum growth hormone was found to reduce in pregnant subjects compared to the non-pregnant control with the lowest decrease observed in the second trimester $(\mathrm{p}<0.05)$. Conversely, serum cortisol increased among pregnant subjects compared to the non-pregnant control, showing a gestational age-dependent increase $(\mathrm{p}<0.05)$. Conclusion: Our findings suggest that serum growth hormone and cortisol vary with gestational age with growth hormone decreasing while cortisol increases. The present study also highlights that parity appears not to have any influence on serum growth hormone and cortisol during normal pregnancy.

Keywords: Pregnancy, gestational age, growth hormone, cortisol, parity.

Copyright $\odot 2022$ The Author(s): This is an open-access article distributed under the terms of the Creative Commons Attribution 4.0 International License (CC BY-NC 4.0) which permits unrestricted use, distribution, and reproduction in any medium for non-commercial use provided the original author and source are credited.

\section{INTRODUCTION}

Pregnancy, also known as gestation represents the period from fertilization of an embryo to childbirth, lasting about nine (9) months and divided into trimesters of three (3) months each. During this period, the body of the mother undergoes significant anatomic, physiologic and metabolic adaptations required to accommodate the fetus as well as to prepare for delivery, lactation and subsequent care of the baby [1]. These adaptations, which are mostly interlinked affect all the body systems and are provoked mostly by hormonal influences of the placenta [2].

To accommodate the fetus, pregnancy is associated with weight gain which may sometimes lead to a change in posture causing musculoskeletal pain and ligamentous laxity which may predispose pregnant women to a greater risk of dislocation [2, 3]. In response to estrogen, progesterone and prostaglandins, there is vascular smooth muscle relaxation leading to increased cardiac output and circulating volume. Blood pressure is maintained with a slight reduction [2, 4]. The circulating progesterone also stimulates the respiratory center enhancing minute ventilation by increasing respiratory rate and tidal volume. With advancing gestation, the enlarging gravid uterus causes an increase in abdominal pressure which decreases chest wall compliance causing a reduction in functional residual capacity (FRC), expiratory reserved volume (ERV) and peak expiratory flow rate [2, 5, 6]. Haematological adaptations include an increase in erythropoiesis leading to increased red cell mass, slightly reduced haemoglobin concentration and platelet count. White blood cells increase significantly with more increase in neutrophils stimulated by estrogen $[2$, 
Amadi Nnaemeka Caleb et al; Sch Int J Obstet Gynec, Jan. 2022; 5(1): 21-25

7]. The enhanced cardiac output increases renal blood flow with a resultant increase in the glomerular filtration rate. As the reabsorption protein and glucose cannot keep pace with the increased glomerular filtration, their values are slightly increased while the serum urea and creatinine are reduced $[8,9]$.

The endocrine system mediates most of the physiological adaptations during pregnancy with the placenta secreting a variant of the human growth hormone (HGH-V) due to the pituitary suppression of the normal growth hormone $(\mathrm{HGH}-\mathrm{H})$. The $\mathrm{HGH}-\mathrm{V}$ does not seem to have a different function from the $\mathrm{HGH}$, it has been shown to play a crucial role in the regulation of maternal and fetal metabolism, as well as in the growth and development of the fetus [10]. The $\mathrm{HGH}-\mathrm{V}$ acts by increasing the levels of Insulin-like growth factor 1 (IGF-1) which generates insulin resistance through its lower lactogenic effects to ensure a contribution of constant glucose [11, 12]. Serum HGH-N levels have been shown to gradually decline during the second half of pregnancy while $\mathrm{HGH}-\mathrm{V}$ continues to appear in maternal circulation with a peak at the first trimester and mid-pregnancy and continues to increase thereafter up to term [13]. Cortisol, commonly referred to as the stress hormone is synthesized by the adrenal cortex in response to stress, emotion and trauma. Its release causes the transport of amino acids from tissues to liver cells for the synthesis of new proteins and the production of more energy. Cortisol has remained an important biomarker of maternal stress [14, 15]. High levels of stress cortisol during pregnancy have been shown as a major potential biological mechanism leading to possible health complications and spontaneous abortion among pregnant women [16-18]. Hence, antenatal maternal stress can negatively affect fetal development, birth outcomes, and overall infant's development [18, 19]. Due to the paucity of data regarding the pattern of changes of maternal growth hormone and cortisol in Nigeria, the present study is aimed at evaluating serum levels of maternal growth hormone and cortisol among apparently healthy pregnant women in Port Harcourt, Nigeria to order access the possible influence of gestational age and parity on these parameters.

\section{MATERIALS AND METHODS \\ Ethical Consideration}

The research design and protocol were approved by the Ethical Review Board of the University of Port-Harcourt
(UPH/CEREMAD/REC/04) and the Ethical Research Committee of the University of Port Harcourt Teaching Hospital (UPTH/ADM/90/S.11/VOL.XI/517). Request for consent form was signed by each prospective participant before recruitment into the study. All procedures in this study were conducted following the highest ethical standards as contained in the World Medical Association (WMA) Helsinki Declaration of 1963 as amended in 2013 [20].

\section{Study Population and Design}

This is a cross-sectional study involving a total of apparently healthy 300 females (21-50yrs) made up of 200 and 100 pregnant females and non-pregnant controls respectively. The pregnant subjects were attending antenatal clinic at the Department of Obstetrics and Gynaecology of the University of Port Harcourt Teaching Hospital while the control subjects were recruited among the staff of the University of Port Harcourt Teaching Hospital. All subjects diagnosed with anaemia, HIV, diabetes mellitus, preeclampsia other endocrine disorders were excluded from the study, both for study and control groups.

\section{Anthropometric measurement, serum sample collection and analysis}

A simple research questionnaire was administered to obtain the age, last menstrual period, gestational age and parity of the subjects. Weight and height were measured using a Secca scale. About $3 \mathrm{ml}$ of venous blood was obtained from each subject and deposited into a plain sample bottle. The samples were centrifuged at $2500 \mathrm{rpm}$ and the supernatant serum was collected and stored at $4^{\circ} \mathrm{C}$. Serum growth hormone and cortisol were analyzed using laboratory ELISA kits (Monobind Inc., U.S.A)

\section{Data Analysis}

The results were analyzed using SPSS version 23.0. The mean and standard deviation were determined for each research group. A t-test was also used to determine the difference in mean of the parameters between the pregnant and non-pregnant subjects. An ANOVA followed by an LSD post hoc analysis was also used to determine the difference among the pregnancy groups. The difference in means were considered significant at $\mathrm{p}<0.05$.

\section{RESULTS}

Table 1: Age, BMI, Cortisol and Growth Hormones Levels among the study population

\begin{tabular}{|l|l|l|l|}
\hline Parameters & Non-pregnant $(\mathbf{n = 1 0 0})$ & Pregnant $(\mathbf{n = 2 0 0})$ & t-test (p-value) \\
\hline Age $($ years $)$ & $33.29 \pm 0.81$ & $31.14 \pm 0.33$ & 0.19 \\
\hline BMI $\left(\mathrm{kg} / \mathrm{m}^{2}\right)$ & $24.10 \pm 0.72$ & $27.72 * \pm 4.89$ & 0.01 \\
\hline Growth $(\mu \mathrm{IU} / \mathrm{ml})$ & $7.81 \pm 2.52$ & $2.55^{*} \pm 0.74$ & 0.01 \\
\hline Cortisol $(\mathrm{ng} / \mathrm{ml})$ & $124.85 \pm 11.84$ & $202.30 * \pm 6.52$ & 0.01 \\
\hline \multicolumn{4}{|c|}{ Data expressed as mean \pm standard deviation } \\
*significantly different compared to non-pregnant control
\end{tabular}


Table 1 shows the mean age, body mass index, serum growth hormone and cortisol hormones values among pregnant and non-pregnant subjects in the study population. The result indicates a significant difference in all the parameters between the pregnant and nonpregnant subjects. The non-pregnant subjects were found to be significantly older $(\mathrm{p}<0.05)$ while mean values of body mass index, serum growth hormone and cortisol were found to be significantly higher among the pregnant subjects compared to their non-pregnant counterparts $(\mathrm{p}<0.05)$.

Table 2: Age, BMI, Serum Growth Hormone and Cortisol Levels among Pregnant subjects in different gestational ages

\begin{tabular}{|c|c|c|c|c|c|}
\hline Parameters & $\begin{array}{c}\text { Non-pregnant } \\
(\mathbf{n}=\mathbf{1 0 0})\end{array}$ & $\begin{array}{c}\text { First trimester } \\
(1-13 w e e k s) \\
(n=76)\end{array}$ & $\begin{array}{c}\text { Second trimester } \\
(14-26 \text { weeks }) \\
(n=75)\end{array}$ & $\begin{array}{c}\text { Third trimester } \\
\text { (27-38 weeks) } \\
(n=49)\end{array}$ & $\begin{array}{l}\text { ANOVA } \\
\text { (p-value) }\end{array}$ \\
\hline Age (Years) & $33.29 \pm 8.08$ & $29.80 * \pm 4.53$ & $32.19 \pm 4.86$ & $31.61 \pm 3.85$ & 0.02 \\
\hline BMI $\left(\mathrm{kg} / \mathrm{m}^{2}\right)$ & $24.10 \pm 7.21$ & $25.66^{*} \pm 4.83$ & $28.14 * \pm 4.10$ & $30.30 * \pm 4.78$ & 0.01 \\
\hline Growth $(\mu \mathrm{IU} / \mathrm{ml})$ & $7.81 \pm 25.25$ & $2.83 \pm 3.74$ & $1.38 * \pm 1.30$ & $3.90 \pm 21.65$ & 0.07 \\
\hline Cortisol (ng/ml) & $124.85 \pm 118.38$ & $161.03 * \pm 71.88$ & $214.53 * \pm 93.68$ & $247.57 * \pm 92.72$ & 0.01 \\
\hline
\end{tabular}

Table 2 show the pattern of variation of age, BMI, serum growth hormones cortisol and levels among pregnant and non-pregnant subjects of different gestational ages. The result indicates a significant variation of these parameters among the research groups. Pregnant subjects in their first trimester were found to be significantly younger compared to the non- pregnant groups $(\mathrm{p}<0.05)$. Also, the mean values of body mass index and serum cortisol showed a significant gestational age-dependent increase $(\mathrm{p}<0.05)$ while a significant decrease in serum growth hormone level was observed for pregnant subjects in their second trimester compared to their non-pregnant counterparts $(\mathrm{p}<0.05)$.

Table 3: The effect of parity on Serum Cortisol and Growth hormone among the pregnant subjects

\begin{tabular}{|l|l|l|l|l|}
\hline Parameters & Nulliparity $(\mathbf{n}=\mathbf{4 3})$ & Multiparity $(\mathbf{n}=67)$ & Grand Multiparity $(\mathbf{n}=\mathbf{1 6})$ & $\begin{array}{l}\text { ANOVA } \\
\text { value })\end{array}$ \\
\hline Age $($ Years $)$ & $28.79 \pm 3.78$ & $31.88^{*} \pm 4.23$ & $33.75^{*} \pm 4.20$ & 0.01 \\
\hline Gestational Age $($ Weeks) & $18.44 \pm 11.03$ & $23.90^{*} \pm 11.55$ & $19.69 \pm 11.51$ & 0.04 \\
\hline BMI $\left(\mathrm{kg} / \mathrm{m}^{2}\right)$ & $27.79 \pm 5.57$ & $28.19 \pm 4.30$ & $29.16 \pm 4.38$ & 0.62 \\
\hline Growth $(\mu \mathrm{IU} / \mathrm{ml})$ & $4.92 \pm 2.30$ & $1.56 \pm 2.56$ & $1.32 \pm 1.95$ & 0.14 \\
\hline Cortisol $(\mathrm{ng} / \mathrm{ml})$ & $188.43 \pm 89.94$ & $221.74 \pm 93.60$ & $229.01 \pm 75.06$ & 0.12 \\
\hline
\end{tabular}

Table 3 show the effect of parity on serum cortisol and growth hormone among pregnant subjects. The result indicates there was a slight increase in the levels of serum cortisol with parity with nulliparous women having the lowest mean value while the grand multiparous pregnant subjects had the highest. However, the reverse was the case for serum growth hormone as the nulliparous subjects were found to have the highest mean growth hormone levels while the grand multiparous subjects had the lowest growth hormone mean values.

\section{DISCUSSION}

This cross-sectional study of 200 pregnant subjects (and 100 non-pregnant control) show that the body mass index (BMI) of pregnant subjects was significantly increased compared to the non-pregnant control (Table 1) $(\mathrm{p}<0.05)$. Also, it was observed as shown in table 2 that the BMI progressively increased significantly with advancing gestation $(p<0.05)$ with the pregnant females in their third trimester having the highest mean value of BMI $(31.61 \pm 3.85)$ compared to the pregnant subjects in their first trimester $(29.80 \pm 4.53)$. The expected maternal weight gain is attributable to the increasing mass of the developing foetus with advancing gestation, the weight of the placenta and the amniotic fluid [21-24]. There were no differences in the body mass index of the nulliparous, multiparous and grand multiparous pregnant subjects in this study, showing that previous pregnancies did not affect maternal weight gain. Excessive gestational weight gain is associated with negative outcomes such as preeclampsia and large birth weight requiring a caesarian delivery $[25,26]$.

A reduction in levels of serum growth hormone in pregnant subjects compared to the nonpregnant control was observed in the study (Table 1) $(\mathrm{p}<0.05)$. It progressively reduced to its lowest value among pregnant subjects in their second trimester when compared to the non-pregnant controls $(p<0.05)$ while increasing slightly among the pregnant subjects in their third trimester. Growth hormone is both released by the pituitary and the placenta during pregnancy with the placenta variant having a suppressing action on the normal growth hormone towards the end of the first trimester [10, 27]. This could be the reason for the reduction in the serum growth hormone observed in the first trimester $(2.83 \mu \mathrm{IU} / \mathrm{ml})$ compared to the second trimester $(1.38 \mu \mathrm{IU} / \mathrm{ml})$. Both variants of the growth hormone do not seem to have a different function as they both regulate maternal and fetal metabolism, as 
well as the growth and development of the fetus [10]. Parity did not have any effect on serum growth hormone among the pregnant subjects.

This study shows a significant increase in serum cortisol in pregnant subjects compared to nonpregnant control (Table 1) $(\mathrm{p}<0.05)$. Among the pregnant subjects, mean values of serum cortisol were observed to show a significant gestational agedependent increase $(\mathrm{p}<0.05)$. Serum cortisol increased from $124.85(\mathrm{ng} / \mathrm{ml})$ in non-pregnant control to 161.03 , 214.53 and $247.57(\mathrm{ng} / \mathrm{ml})(29,56$ and $58 \%$ increase) for first, second and third trimesters respectively (Table 2 ). As pregnancy progresses, the pregnant woman is exposed to stressors leading to the release of cortisol via the HPA-axis which helps the body to adjust and recover [28-31]. Additional cortisol and cortisol releasing hormone $(\mathrm{CRH})$ are also produced by the placenta during the second and third trimesters. It has also been noted that there is a possible source of ACTH which may not be subject to negative feedback control or an alteration in the ACTH precursor protein produced by the pituitary and/or placenta. A placental barrier protects the growing fetus from these copious quantities of maternal cortisol. However, a higher than normal quantity of secreted maternal cortisol can weaken the placental barrier leading to teratogenic effects, reduced fetal growth, preterm birth [32, 33] and reduced cognitive skills of the offspring [29]. When controlled for maternal and gestational ages, it was observed that serum cortisol showed a marginal increase among multiparous and grand multiparous pregnant subjects when compared with nulliparous subjects (Table 3). This could be due to the observed increase in gestational age which increases the levels of serum cortisol as already shown in the study. However, this marginal increase was not significant $(\mathrm{P}>0.05)$. Maternal cortisol (hair cortisol concentration) has been shown to be higher in nulliparous pregnant subjects compared to their multiparous counterparts due to greater pregnancy-related distress among nulliparas compared to multiparas [34, 35]. Parity has long been associated with pregnancy outcomes like birth weight and infant growth rate with nulliparas having smaller and slower-growing babies [35-37].

\section{CONCLUSION}

Our findings suggest that serum growth hormone and cortisol vary with gestational age with growth hormone decreasing while cortisol increases. The present study also highlights that parity appears not to have any influence on serum growth hormone and cortisol during normal pregnancy.

\section{REFERENCES}

1. Longo, L. D. (2018). Maternal Physiology of Pregnancy. In The Rise of Fetal and Neonatal Physiology, Springer.

2. Talbot, L., \& Maclennan, K. (2016). Physiology of Pregnancy. Anaesthesia \& Intensive Care Medicine, 17(7), 341-345.

3. Ireland, M. L., \& Ott, S. M. (2000). The Effects of Pregnancy on the Musculoskeletal System. Clinical Orthopaedics and Related Research $囚, 372,169-$ 179.

4. Kodogo, V., Azibani, F., \& Sliwa, K. (2019). Role of Pregnancy Hormones and Hormonal Interaction on the Maternal Cardiovascular System: A Literature Review. Clinical Research in Cardiology, 1-16.

5. LoMauro, A., \& Aliverti, A. (2015). Respiratory Physiology of Pregnancy: Physiology Masterclass. Breathe, 11(4), 297-301.

6. Chinko, B. C., \& Green, K. I. (2014). Peak Expiratory Flow Rate of Pregnant Women in Port Harcourt. International Research Journal of Medical Sciences, 2(6), 1-5.

7. Chandra, S., Tripathi, A. K., Mishra, S., Amzarul, M., \& Vaish, A. K. (2012). Physiological Changes in Hematological Parameters During Pregnancy. Indian Journal of Hematology And Blood Transfusion, 28(3), 144-146.

8. Maynard, S. (2020) Renal Physiology in Pregnancy. In Obstetric and Gynecologic Nephrology, Springer.

9. Belzile, M., Pouliot, A., Cumyn, A., \& Côté, A. M. (2019). Renal Physiology and Fluid and Electrolyte Disorders in Pregnancy. Best Practice \& Research Clinical Obstetrics \& Gynaecology, 57, 1-14.

10. Handwerger, S., \& Freemark, M. (2000). The Roles of Placental Growth Hormone and Placental Lactogen in the Regulation of Human Fetal Growth and Development. Journal of Pediatric Endocrinology and Metabolism, 13(4), 343-356.

11. Lacroix, M., Guibourdenche, J., Frendo, J., Muller, F., \& Evain-Brion, D. (2002). Human Placental Growth Hormone-a Review. Placenta, 23, S87S94.

12. Guibourdenche, J., Fournier, T., Malassin $\breve{A} \breve{S}$, A., and Evain-Brion, D. (2009) Development and Hormonal Functions of the Human Placenta. Folia Histochemica et Cytobiologica 47 (5), 35-40.

13. Frankenne, F., Closset, J., Gomez, F., Scippo, M. L., Smal, J., \& Hennen, G. (1988). The Physiology of Growth Hormones (Ghs) in Pregnant Women and Partial Characterization of the Placental Gh Variant. The Journal of Clinical Endocrinology \& Metabolism, 66(6), 1171-1180.

14. D'Anna-Hernandez, K. L., Ross, R. G., Natvig, C. L., \& Laudenslager, M. L. (2011). Hair Cortisol Levels as a Retrospective Marker of Hypothalamic-Pituitary Axis Activity Throughout Pregnancy: Comparison to Salivary Cortisol. Physiology \& Behavior, 104(2), 348-353. 
15. Baibazarova, E., van de Beek, C., Cohen-Kettenis, P. T., Buitelaar, J., Shelton, K. H., \& van Goozen, S. H. (2013). Influence of Prenatal Maternal Stress, Maternal Plasma Cortisol and Cortisol in the Amniotic Fluid on Birth Outcomes and Child Temperament at 3 Months. Psychoneuroendocrinology, 38(6), 907-915.

16. Austin, M. P., \& Leader, L. (2000). Maternal Stress and Obstetric and Infant Outcomes: Epidemiological Findings and Neuroendocrine Mechanisms. Australian and New Zealand Journal of obstetrics and gynaecology, 40(3), 331-337.

17. Lobel, M., Cannella, D. L., Graham, J. E., DeVincent, C., Schneider, J., \& Meyer, B. A. (2008). Pregnancy-Specific Stress, Prenatal Health Behaviors, and Birth Outcomes. Health Psychology, 27(5), 604.

18. Nepomnaschy, P. A., Welch, K. B., McConnell, D. S., Low, B. S., Strassmann, B. I., \& England, B. G. (2006). Cortisol Levels and Very Early Pregnancy Loss in Humans. Proceedings of the National Academy of Sciences, 103(10), 3938-3942.

19. Bolten, M.I., Wurmser, H., Buske-Kirschbaum, A., Papoušek, M., Pirke, K. M., \& Hellhammer, D. (2011). Cortisol Levels in Pregnancy as a Psychobiological Predictor for Birth Weight. Archives of Women's Mental Health, 14(1), 33-41.

20. WMA. (2013). Wma Declaration of Helsinki Ethical Principles for Medical Research Involving Human Subjects. The World Medical Association, Inc https://www.wma.net/policies-post/wmadeclaration-of-helsinki-ethical-principles-formedical-research-involving-human-subjects/.

21. Abrams, B., \& Selvin, S. (1995). Maternal Weight Gain Pattern and Birth Weight. Obstetrics \& Gynecology, 86(2), 163-169.

22. Hutcheon, J. A., \& Bodnar, L. M. (2018). Good Practices for Observational Studies of Maternal Weight and Weight Gain in Pregnancy. Paediatric and Perinatal Epidemiology, 32(2), 152.

23. Liang, C. C., Chao, M., Chang, S. D., \& Chiu, S. Y. H. (2021). Pregnancy Weight Gain May Affect Perinatal Outcomes, Quality of Life During Pregnancy, and Child-Bearing Expenses: An Observational Cohort Study. Archives of Gynecology and Obstetrics, 1-10.

24. Odeniyi, I., Fasanmade, O., Ogbera, A., \& Ohwovoriole, A. (2015). Body Mass Index and Its Effect on Serum Cortisol Level. Nigerian Journal of Clinical Practice, 18(2), 194-197.

25. Johnson, J., Clifton, R. G., Roberts, J. M., Myatt, L., Hauth, J. C., Spong, C. Y., Varner, M. W., Wapner, R. J., Thorp Jr, J. M., \& Mercer, B. M. (2013) Pregnancy Outcomes with Weight Gain above or Below the 2009 Institute of Medicine Guidelines. Obstetrics and Gynecology, 121(5), 969.
26. Vlachadis, N. (2013). Pregnancy Outcomes with Weight Gain above or Below the 2009 Institute of Medicine Guidelines. Obstetrics and Gynecology, 122(3), 696-697.

27. Lacroix, M. C., Guibourdenche, J., Frendo, J. L., Muller, F., \& Evain-Brion, D. (2002). Human Placental Growth Hormone-a Review. Placenta, 23, S87-S94.

28. de Wolf, G. (2010). Perinatal Health Epidemiology in Multi-Ethnic Amsterdam: Psychobiological Processes. Universiteit van Amsterdam [Host].

29. LeWinn, K. Z., Stroud, L. R., Molnar, B. E., Ware, J. H., Koenen, K. C., \& Buka, S. L. (2009). Elevated Maternal Cortisol Levels During Pregnancy Are Associated with Reduced Childhood Iq. International Journal of Epidemiology, 38(6), 1700-1710.

30. Carr, B. R., Parker Jr, C. R., Madden, J. D., MacDonald, P. C., \& Porter, J. C. (1981). Maternal Plasma Adrenocorticotropin and Cortisol Relationships Throughout Human Pregnancy. American Journal of Obstetrics and Gynecology, 139(4), 416-422.

31. Akinloye, O., Obikoya, O., Jegede, A., Oparinde, D., \& Arowojolu, A. (2013). Cortisol Plays Central Role in Biochemical Changes During Pregnancy. International Journal of Medicine and Biomedical Research, 2(1), 3-12.

32. Carmichael, S. L., \& Shaw, G. M. (2000). Maternal Life Event Stress and Congenital Anomalies. Epidemiology, 11(1), 30-35.

33. Wadhwa, P.D., Dunkel-Schetter, C., Chicz-DeMet, A., Porto, M., and Sandman, C.A. (1996) Prenatal Psychosocial Factors and the Neuroendocrine Axis in Human Pregnancy. Psychosomatic Medicine, 58(5), 432-446.

34. Vleugels, M. P., Eling, W. M., Rolland, R., \& de Graaf, R. (1986) Cortisol Levels in Human Pregnancy in Relation to Parity and Age. American Journal of Obstetrics and Gynecology, 155(1), 118-121.

35. Huo, Y., Cheng, L., Wang, C., Deng, Y., Hu, R., Shi, L., Wan, Q., Chen, L., Zeng, T., \& Yu, X. (2021). Associations between Parity, Pregnancy Loss, and Breastfeeding Duration and Risk of Maternal Type 2 Diabetes: An Observational Cohort Study. Journal of Diabetes.

36. Scholl, T. O., Hediger, M. L., Huang, J., Johnson, F. E., Smith, W., \& Ances, I. G. (1992). Young Maternal Age and Parity Influences on Pregnancy Outcome. Annals of Epidemiology 2(5), 565-575.

37. Bai, J., Wong, F.W. S., Bauman, A., \& Mohsin, M. (2002). Parity and Pregnancy Outcomes. American Journal of Obstetrics and Gynecology, 186(2), 274-278. 